\title{
Effect of Republic Act 10963 "Tax reform for Acceleration and inclusion (Train) Law" on the collection Performance in Income Tax of one Revenue District in Nueva Ecija
}

\author{
Arianne Dawn R. Cuellar, Sharmine S. Lopez, Sheryl A. Pingkian, Dean Victoria M. \\ Reyes, Marilou P. Pascual
}

Revenue District Office 23b-South Nueva Ecija, Sumacab Este, Cabanatuan City Graduate School, Nueva Ecija University of Science and Technology, Philippines

Received: 05 May 2021; Received in revised form: 03 Jun 2021; Accepted: 16 Jun 2021; Available online: 23 Jun 2021

\begin{abstract}
The study was conducted in one of Nueva Ecija's Revenue District Offices. Thirty (30) revenue officers assigned to the assessment, client assistance, collection, and compliance sections, as well as twenty (20) taxpaying citizens, participated in the study. The researchers found out that the effects of the TRAIN LAW on the collection performance in Income Tax for the taxable year 2018 and 2019 of the said revenue district office gradually improved on its full implementation by the year 2019, despite the decrease in collections from the personal income taxes of purely compensation and purely business income earners but still the collections from mixed-income earners [1] increases in 2018 and there is a positive growth in tax revenues collected from personal income taxes in 2019.
\end{abstract}

Keywords-Collection, income tax, revenue, taxation, TRAIN Law.

\section{INTRODUCTION}

"President Rodrigo Roa Duterte signed into law Republic Act No. 10963, otherwise known as the Tax Reform for Acceleration and Inclusion (TRAIN) Act, the first package of the Comprehensive Tax Reform Program (CTRP, on December 19, 2017, in Malacanang. The TRAIN will provide hefty income tax cuts for the majority of Filipino taxpayers while raising additional funds to help support the government's accelerated spending on its "Build, Build, Build" and social services programs" [2]. The TRAIN Act aims to produce revenue in order to realize the Duterte administration's 2022 and 2040 visions, which include eradicating extreme poverty, creating inclusive institutions that provide equal opportunities for all, and achieving higher income country status. It also aims to make the tax system more straightforward, equitable, and efficient [3].

After the implementation of the TRAIN law, several researchers have ventured on studying its effects or impact in different societies, communities, and groups of people. Boco et al (2019) found out that "the impact of TRAIN law to the poor are mostly the basic need such as food in This article can be downloaded from here: www.ijaems.com which it is needed to reduce their budget for them to survive since there are other things that needed to be paid such like utility bills and debts. Furthermore, it also affects the mental and well-being of a person such as anxiety, stress, and depression due to financial problems. It is therefore concluded that after the implementation of TRAIN the poor income class families become poorer" [4]. In a related study by [5], they found that revealed in terms of the affordability of necessary goods and services, social overhead capital and infrastructure, and the development of micro-enterprises, the effect or impact of the TRAIN Law on consumers was moderately evident, while in terms of the affordability of non-essential commodities and disposable income, the effect or impact was only slightly evident. It was found that, despite the fact that assessing the complete impact of TRAIN on various aspects of the economy is still premature because the program is still in its early stages of implementation, people still perceive an improvement in the delivery of public services and infrastructures. This study, although similar to those presented in terms of the impact and effect 
of the TRAIN law, it differs as to the locale and the respondents, and since it dealt on the collection performance in income tax of one Revenue District in Nueva Ecija, in the Philippines, which are dearth in the country.

\section{METHODOLOGY}

A descriptive research design was adopted in this study. 'Descriptive research systematically explains a scenario, problem, phenomena, service or program, attitude toward an issue, or simply, it gives knowledge about a subject,' according to [6], as referenced by the writers in [7] and [8]. This research looked into the tax collection and compliance of one of Nueva Ecija's district offices. The study's respondents were chosen on the basis of the following criteria [9]: they must be a revenue officer and a taxpayer within the district office's jurisdiction, have worked as a revenue officer for at least two years, and have been a taxpayer for at least one year. Thirty (30) revenue officers assigned to the assessment, collection, client assistance, and compliance sector, as well as twenty (20) taxpaying citizens, were chosen as respondents. The information came from the respondents' responses to a questionnaire created by the researchers. The research was conducted from 2018 to 2019.

\section{RESULTS AND DISCUSSION}

\section{Reported Collections of Income Taxes from Individuals}

The Revenue District Office has its monthly tax collections from the individual taxpayers. Based on its generated report, tax collected is classified into pure compensation, pure business, mixed-income, withholding tax on wages, expanded creditable withholding tax, final tax, capital gains, and non-resident citizens. Table 1 shows the annual collection for the years 2016 and 2017 before TRAIN is implemented.

Table 1. Annual Collection of RDO 23-B from Individual Taxpayers for the years 2016 and 2017

\begin{tabular}{|c|c|c|c|c|}
\hline \multicolumn{2}{|r|}{ Type } & 2016 & 2017 & $\begin{array}{c}\text { Percentage } \\
\text { Change }\end{array}$ \\
\hline a. & Pure Compensation & $1,563,632.17$ & $4,278,187.30$ & $173.61 \%$ \\
\hline b. & Pure Business & $70,187,795.50$ & $74,518,726.74$ & $6.17 \%$ \\
\hline c. & $\begin{array}{l}\text { Mixed Income/Income from } \\
\text { profession }\end{array}$ & $85,473.71$ & $2,770,394.39$ & $3141.22 \%$ \\
\hline d. & $\begin{array}{l}\text { Withholding } \\
\text { Compensation }\end{array}$ & $786,259,134.06$ & $964,353,703.63$ & $22.65 \%$ \\
\hline e. & $\begin{array}{l}\text { Expanded } \\
\text { Withholding Tax }\end{array}$ & $92,787,861.58$ & $172,021,720.90$ & $85.39 \%$ \\
\hline f. & Final tax & $1,435,359.54$ & $5,632,949.68$ & $292.44 \%$ \\
\hline g. & Capital Gains & $97,437,497.81$ & $115,043,080.34$ & $18.07 \%$ \\
\hline h. & Non-resident Citizens & - & $24,000.00$ & \\
\hline & tal Collections & $1,049,756,754.37$ & $1,338,642,762.98$ & $27.52 \%$ \\
\hline
\end{tabular}

The table depicted that the RDO's collection performance in 2017 improved by $27.52 \%$ as compared to 2016. This was because of the priority programs of BIR (enhancement of voluntary compliance among taxpayers, Run After Tax Evaders (RATE) and "Oplan Kandado) and continuous comprehensive awareness campaign to the public regarding the importance of paying taxes and that they can help by asking receipts or invoices from the establishments they dealt with. Table 2 shows the annual collection of RDO when the RA 10963 was implemented. 
Table 2. Annual Collection of RDO 23-B from Individual Taxpayers for the years 2018 and 2019

\begin{tabular}{lrr}
\hline \multicolumn{1}{c}{ Type } & $\mathbf{2 0 1 8}$ & $\mathbf{2 0 1 9}$ \\
\hline Personal Income Taxes: & & $3,728,138.74$ \\
a. Pure Compensation & $2,779,069.11$ & $156,922,742.08$ \\
b. Pure Business & $56,979,325.44$ & $38,198,536.84$ \\
c. Mixed Income & $13,201,188.21$ & \\
Other Income Taxes: & & $500,517,341.42$ \\
d. Withholding Tax on Compensation & $459,675,724.71$ & $599,233,430.61$ \\
e. Expanded Creditable Withholding Tax & $98,261,340.49$ & $24,371,391.07$ \\
f. $\quad$ Final tax & $4,399,147.50$ & $65,564,718.28$ \\
g. Capital Gains & $123,015,191.95$ & $60,340.58$ \\
h. Non-resident Citizens & $22,200.00$ & $\mathbf{1 , 3 8 8 , 5 9 6 , 6 3 9 . 6 2}$ \\
\hline Total Collections & $\mathbf{7 5 8 , 3 3 3 , 1 8 7 . 4 1}$ & \\
\hline
\end{tabular}

\section{Changes in the Collection of Income Taxes after Implementation of TRAIN Law}

The goal of TRAIN is to increase the tax revenues of the government to finance infrastructure projects, education, and health services. From Tables 1 and 2, the percentage change can be determined to compare with the normal change before TRAIN is implemented.

Table 3. Percentage Change in 2017 and 2018 - Annual Collection from Individual Taxpayers

\begin{tabular}{lrr}
\hline \multicolumn{1}{c}{ Type } & Increase (Decrease) & Percentage Change \\
\hline Personal Income Taxes: & & $(35.04 \%)$ \\
a. Pure Compensation & $(1,499,118.19)$ & $(23.54 \%)$ \\
b. Pure Business & $(17,539,401.30)$ & $376.51 \%$ \\
c. Mixed Income/Income from profession & $10,430,793.82$ & $(52.33 \%)$ \\
Other Income Taxes: & & $(42.88 \%)$ \\
d. Withholding Tax on Compensation & $(504,677,978.92)$ & $(21.90 \%)$ \\
e. Expanded Creditable Withholding Tax & $(1,233,802.18)$ & $6.93 \%$ \\
f. Final tax & $(7,972,111.61)$ & $(7.50 \%)$ \\
g. Capital Gains & $(1,800.00)$ & $(\mathbf{4 3 . 3 5 \% )}$ \\
h. Non-resident Citizens & $(\mathbf{5 8 0 , 3 0 9 , 5 7 5 . 5 7 )}$ & \\
\hline Total Collections & & \\
\hline
\end{tabular}

As shown in Table 3, the total collections decreased by $43.35 \%$. Only the collections from mixed-income and capital gains increase. The collections from the personal income taxes (pure compensation and pure business) decrease while the collections from mixed-income earners increases. Based on analysis and interviews of the employees, the number one cause of the decline is the increase of the threshold to P 250,000 before an individual taxpayer is subject to graduated tax rates. Most of these taxpayers are under RDO and are low middle-income This article can be downloaded from here: www.ijaems.com earners who were previously taxed on their earnings before January 1, 2018. The increased collection from mixedincome earners can be attributed to the availability of the option to use a flat rate of $8 \%$ on gross income. Other contributing factors were: (1) the agency is not yet prepared with the regulations, rulings, and guidelines due to immediate implementation of the law in January 2018 after it was signed in December 2017 by President Duterte; (2) the tax returns were published late; (3) there was inadequate dissemination of information to the taxpayers; 
and (4) there was no proper and suitable training both to the BIR employees and the taxpayers. These factors resulted in confusion in both parties and improper implementation of the Act in 2018. In the second year of TRAIN's effectiveness, it can be observed in Table 4 that there was an enormous increase in the collections. An amount equivalent to $\mathrm{P} 630,263,452.21$ or $83.11 \%$ was the computed effect of the change. The collection growth in 2019 is twice higher than the normal increase of $27.52 \%$ (Table 1) before the law was implemented. Having these figures, it can be inferred that TRAIN's objective to increase collections of tax revenues of the government is achieved by BIR RDO 23-B South Nueva Ecija.

Table 4. Percentage Change in 2018- and 2019- Annual Collection from Individual Taxpayers

\begin{tabular}{|c|c|c|}
\hline Type & Increase (Decrease) & Percentage Change \\
\hline \multicolumn{3}{|l|}{ Personal Income Taxes: } \\
\hline a. Pure Compensation & $949,069.63$ & $34.15 \%$ \\
\hline b. Pure Business & $99,943,416.64$ & $175.40 \%$ \\
\hline $\begin{array}{l}\text { c. Mixed-Income/Income from the } \\
\text { profession }\end{array}$ & $24,997,348.63$ & $189.36 \%$ \\
\hline \multicolumn{3}{|l|}{ Other Income Taxes: } \\
\hline d. Withholding Tax on Compensation & $40,841,616.71$ & $8.88 \%$ \\
\hline e. Expanded Creditable Withholding Tax & $500,972,090.12$ & $509.84 \%$ \\
\hline f. Final tax & $19,972,243.57$ & $454.00 \%$ \\
\hline g. Capital Gains & $(57,450,473.67)$ & $(46.70 \%)$ \\
\hline h. Non-resident Citizens & $38,140.58$ & $171.80 \%$ \\
\hline Total Collections & $630,263,452.21$ & $83.11 \%$ \\
\hline
\end{tabular}

From the viewpoint of the tax collectors, the increase was due to the efficient and effective dissemination of information to the taxpayers. Relative memorandums and advisories were issued to facilitate ease of application of TRAIN. There were trainings conducted for the BIR employees. Also, the agency held consultation meetings with the accountants of business establishments and tax practitioners to address the issues encountered in 2018 and the procedures that are confusing and difficult to comply.
The analysis further revealed in Table 5 that the withholding tax on wages on employees declines almost $50 \%$ in 2018 and 2019. This is a manifestation that individual taxpayers received higher net pay or higher share in business profit especially those that are below the middle-income earner's bracket. Another objective of the TRAIN is attained.

Table 5. Effect on Withholding Tax on Compensation

\begin{tabular}{|c|c|c|c|c|c|}
\hline & \multicolumn{2}{|c|}{$\begin{array}{l}\text { Annual Collection BEFORE TRAIN } \\
\text { is implemented }\end{array}$} & \multicolumn{2}{|c|}{$\begin{array}{l}\text { Annual Collection AFTER TRAIN is } \\
\text { implemented }\end{array}$} & \multirow[b]{2}{*}{$\begin{array}{c}\text { Net Increase } \\
\text { (Decrease) }\end{array}$} \\
\hline & 2016 & 2017 & 2018 & 2019 & \\
\hline Collections & $786,259,134.06$ & $964,353,703.63$ & $459,675,724.71$ & $500,517,341.42$ & $(45.15 \%)$ \\
\hline
\end{tabular}

The decrease in withholding taxes in compensation comes with the increase in the collection of other withholding taxes at the source. Table 6 shows the change in the average annual collection after the TRAIN took effect. The examination of monthly collections in 2019 discovered that the increase happened to start the month of April when the Revised BIR Form No. 1701 (Annual Income Tax Return for Individuals, Estates, and Trusts) issued on March 18, 2019, is due for filing and payment. 


\begin{tabular}{|c|c|}
\hline & $\begin{array}{c}\text { International Journal of Advanced Engineering, Management and Science } \\
\text { (IJAEMS) } \\
\text { Peer-Reviewed Journal }\end{array}$ \\
INF & ISSN: 2454-1311 / Vol-7, Issue-6; Jun, 2021 \\
P U B L IC A T I O N & Journal Home Page: https://ijaems.com/ \\
& Article DOI: https://dx.doi.org/10.22161/ijaems.76.11 \\
\hline
\end{tabular}

Table 6. Effect on Other Withholding Tax at Source

\begin{tabular}{lccc}
\hline & $\begin{array}{c}\text { Average Annual Collection } \\
\text { BEFORE TRAIN is } \\
\text { implemented }\end{array}$ & $\begin{array}{c}\text { Average Annual Collection } \\
\text { AFTER TRAIN is } \\
\text { implemented }\end{array}$ & $\begin{array}{c}\text { Net Increase } \\
\text { (Decrease) }\end{array}$ \\
\hline Creditable Withholding Tax & $112,903,169.01$ & $274,174,706.74$ & $\mathbf{1 4 2 . 8 4 \%}$ \\
$\begin{array}{l}\text { Creditable Withholding Tax on } \\
\text { Real Property Other than Capital }\end{array}$ & $19,501,622.24$ & & $\mathbf{2 8 2 . 3 9 \%}$ \\
$\begin{array}{l}\text { Asset } \\
\text { Final Taxes }\end{array}$ & $3,534,154.61$ & $14,385,269.29$ & $\mathbf{3 0 7 . 0 4 \%}$ \\
\hline Total & $\mathbf{1 3 5 , 9 3 8 , 9 4 5 . 8 6}$ & $\mathbf{3 6 3 , 1 3 2 , 6 5 4 . 8 4}$ & $\mathbf{1 6 7 . 1 3 \%}$ \\
\hline
\end{tabular}

The revised BIR form is issued to be used by the individuals (including those with mixed-income), estates, and trusts in filing the annual income tax return and paying the income tax due starting the year 2018 that is due on or before April 15, 2019. This issuance is in consonance to RR 11-2018 [Amending Certain Provisions of Revenue Regulations No. 2-98, as Amended, to Implement Further Amendments Introduced by Republic Act No. 10963, Otherwise Known as the "Tax Reform for Acceleration and Inclusion (TRAIN)" Law, Relative to Withholding of Income Tax] as implemented by RMO 26-2018 (Prescribing the Guidelines in Monitoring, Identification, Inclusion and Deletion of Top Withholding Agents Pursuant to the Pertinent Provisions of Revenue Regulations No. 11-2018) issued in 2018. The said RR is effective November 1, 2018, but the implementation was delayed until revised BIR Form 1701 was published.

\section{CONCLUSIONS AND RECOMMENDATIONS}

In light of the above findings, the following conclusions and recommendations were drawn: 1. The collection performance of the Revenue District declined in 2018 and gradually improved in 2019 after the full implementation of RA 10963 or TRAIN Law. 2. The collections from the personal income taxes of purely compensation and purely business income earners decrease while the collections from mixed-income earners increase in 2018. There is a positive growth in tax revenues collected from personal income taxes in 2019. 3. The collection of other withholding taxes at source increased in 2018 and 2019 due to RR 11-2018 as implemented by RMO 26-2018. 4. To continue its comprehensive awareness campaign to the taxpayers and support the agency's priority programs on the enhancement of voluntary compliance among taxpayers, Run After Tax Evaders (RATE) and "Oplan Kandado. 5. To increase tax collection the district office should increase the consultation meetings with its stakeholders for a prompt response on the issues and concerns. This will enhance the effectiveness and efficiency of tax administration and collection. The elements and recommendations are all significant and important for the district office's effective collection and performance when the TRAIN Law is implemented. However, these are impossible to adopt at the same time because the agency was fully equipped at the Act's enactment to handle all of the agency's internal contributing variables. Management may have the same goals in mind to improve the agency's performance, but they are unable to do it owing to circumstances beyond their control. The most significant proposal that has to be implemented in order to maintain employee professionalization is that a continual program for training employees in the right application of tax laws, as well as the development and enhancement of their professional 
competence, be implemented. Lastly, "research on the same discipline with more respondents should be conducted to be able to make accurate decisions given much available data or information [10] to further validate the findings of this study".

\section{REFERENCES}

[1] BIR.gov.ph. Revenue Memorandum Circular No. 37-2019 Circularizing the Availability of the Enhanced BIR Form No. 1701 [Annual Income Tax Return for Individuals (including MIXED Income Earner), Estates and Trusts] January 2018 (ENCS). www.br.gov.ph

[2] Department of Finance. (2017). The Tax Reform for Acceleration and Inclusion (TRAIN) Act. https://www.dof.gov.ph/ra-10963-train-law-and-vetomessage-of-the-president/

[3] About the Tax Reform - What is TRAIN? \#TaxReformNow". \#TaxReformNow. Retrieved July 19, 2019.

[4] Boco, R. et al. (2019). The Impact of Tax Reform for Acceleration and Inclusion (TRAIN) Law on Poor Income Class Families: A Phenomenological Study. University of Immaculate Conception Annex Campus Bonifacio St., Davao City 8000 Davao del Sur, Philippines

[5] Bonghanoy, C. et al. (2019). Stakeholders' Perspective on the Implementation of Train Law in Cebu City, Philippines. Asian Journal of Managerial Science ISSN: 2249-6300 Vol. 8 No. 2, 2019, pp. 55-63.

[6] Kumar, R. Research Methodology: A step-by-step guide for beginners (4th.ed.) SAGE, CA: Thousand Oaks.2014

[7] Subia, G.S., Trinidad, C.L., R.R., Medrano, H.B. \& Manuzon, E.P. Learning Styles and Preferred Teaching Styles of Master of Arts and Teaching (MAT), major in Vocational Technological Education (VTE) Generation Y Learners, International Journal of English Literature and Social Sciences (IJELS) Vol-4, Issue 2, Mar-Apr, 2019. https://dx.doi.org/10.22161/ijels.4.2.35.

[8] Jocson, J., Florencondia, N. and Subia, G. (2019). Flood Prevention and Mitigation Initiatives towards a Flood-Free City. American Scientific Research Journal for Engineering, Technology, and Sciences (ASRJETS) (2019) Volume 58, No 1, pp 215-224.

[9] Subia, G. (2018) Comprehensible Technique in Solving Consecutive Number Problems in Algebra. Journal of Applied Mathematics and Physics, 6, 447-457. Doi:10.4236/jamp.2018.63041.

[10] Subia, Gener S. (2018). Think Like My Teacher (TLMT): A New Method in Assessing Millennial Learners. International Journal of Arts, Humanities and Social Sciences. Volume 3. Issue 1.www.ijahss.co 